\title{
Age structure in a newly established and increasing population: initially high proportion of young birds among nesting Great Grey Owls
}

\author{
Geir A. Sonerud ${ }^{1}$ (D) $\cdot$ Roar Solheim² $\cdot$ Trond Berg $^{3}$
}

Received: 23 December 2019 / Revised: 22 May 2020 / Accepted: 6 August 2020 / Published online: 16 August 2020

(c) The Author(s) 2020

\begin{abstract}
The mechanisms behind expansions of the distribution of a bird species and the ensuing establishment of new populations are poorly known. The distribution of Great Grey Owl (Strix nebulosa) in the western Palearctic has generally expanded towards southwest during the past fifty years, and particularly so in Fennoscandia. In the past decade, the recorded breeding population in Norway, confined to Hedmark county bordering Sweden, increased from 1 pair in 2009 to $>100$ pairs in 2017-2018, extending the southwestern border of the distribution $>100 \mathrm{~km}$. We studied the age structure of this expanding population based on the molting pattern of the wing feathers of birds captured at the nest site for banding and of non-captured birds photographed in flight. In Fennoscandia the Great Grey Owl relies on shrews and microtine rodents, which usually fluctuate in 3-4 years cycles. The proportion of 1-year old birds among the nesting Great Grey Owls was higher in peak year two of each small mammal population cycle (2011, 2014 and 2018) than in peak year one (2010, 2013 and 2017), and was particularly high (77\%) in 2011 when the owl population was far lower (22 nestings recorded) than in later corresponding years (64 nestings in 2014 and 103 in 2018). Thus, this population seems to have been founded to a large extent by birds nesting as 1 year olds, and most likely having dispersed from Sweden. The ability to determine the age of Great Grey Owls without having to capture them extended our data set, in particular for males, which are more reluctant to attack intruders at the nest site and, therefore, less likely to be captured for banding. Being able to age a bird without having to capture it is important, because trapping does not sample a bird population randomly.
\end{abstract}

Keywords Age $\cdot$ Founder population $\cdot$ Molt $\cdot$ Population fluctuations $\cdot$ Small mammals $\cdot$ Strix nebulosa

\section{Zusammenfassung}

Altersstruktur in einer neu entstandenen und wachsenden Population: anfänglich hoher Anteil an Jungvögeln bei brütenden BartkäuzenDie Mechanismen hinter der zunehmenden Verbreitung einer Vogelart und der damit einhergehenden Etablierung neuer Populationen sind kaum bekannt. Die Verbreitung des Bartkauzes (Strix nebulosa) in der Westpaläarktis hat sich in den letzten fünfzig Jahren allgemein nach Südwesten ausgedehnt, vor allem in Fennoskandien. In den letzten zehn Jahren nahm die erfasste Brutpopulation in Norwegen, die auf den an Schweden angrenzenden Bezirk Hedmark beschränkt war, von einem Paar in 2009 auf >100 Paare in 2017-2018 zu, was zu einer zunehmenden Verbreitung der südwestlichen Grenze um $>100 \mathrm{~km}$ führte. Wir untersuchten die Altersstruktur dieser zunehmenden Population basierend auf dem Mausermuster

Communicated by O. Krüger.

Geir A. Sonerud

geir.sonerud@nmbu.no

Roar Solheim

roar.solheim@uia.no

Trond Berg

tr-ber3@online.no
1 Faculty of Environmental Sciences and Natural Resource Management, Norwegian University of Life Sciences, P. O. Box 5003, NO-1432 As, Norway

2 Natural History Museum, Agder University, P. O. Box 422, NO-4604 Kristiansand, Norway

3 Natural History Unit, Norwegian Broadcasting Corporation, Grønnegt. 67, NO-2317 Hamar, Norway 
der Flügelfedern der Vögel, die am Nistplatz zur Beringung gefangen wurden, und nicht gefangenen Individuen, die im Flug fotografiert wurden. In Fennoskandien ist der Bartkauz auf Spitz- und Wühlmäuse angewiesen, dessen Bestände gewöhnlich in Zyklen von 3-4 Jahren schwanken. Der Anteil der einjährigen Bartkäuze innerhalb der brütenden Population war im zweiten Spitzenjahr der Zyklen jeder Kleinsäugerpopulation (2011, 2014 und 2018) höher als im ersten Spitzenjahr (2010, 2013 und 2017). Im Jahr 2011 war der Anteil an Einjährigen besonders hoch (77\%), obwohl die Bartkauzpopulation viel kleiner war (22 Nester erfasst) als in den späteren entsprechenden Jahren (64 Nester in 2014 und 103 in 2018). Somit scheint diese Population vor allem von Vögeln gegründet worden zu sein, die als einjährige Vögel brüteten und sich höchstwahrscheinlich von Schweden aus ausgebreitet haben. Die Möglichkeit, das Alter von Bartkäuzen zu bestimmen, ohne diese fangen zu müssen, hat unseren Datensatz insbesondere bei den Männchen erweitert, die eher Eindringlinge am Nistplatz durch Angriffe zurückhalten und daher mit geringerer Wahrscheinlichkeit bei der Beringung gefangen werden. Die Altersbestimmung eines Vogels, ohne diesen fangen zu müssen, ist bedeutend, da ein Fang zu keiner zufälligen Stichprobe der Vogelpopulation führt.

\section{Introduction}

The colonization of new areas by a bird species through natural expansion of the breeding range, from the arrival of the first individuals to the establishment of a population, is fundamental for our understanding of avian speciation and population ecology in general, and of the effects of human activities and climate change in particular (Newton 2003). Still, the mechanisms behind such expansions are poorly known, mainly because such events are rarely directly observed in detail (Karvonen et al. 2012). These mechanisms may be intricate, as revealed for the cyclic replacement of one cavity nester by another in ephemeral habitat created by forest fire in Montana, USA; of the rapidly dispersing but poorly competitive Mountain Bluebird (Sialia currucoides) by the slowly dispersing but more competitive Western Bluebird (Sialia mexicana) (Duckworth and Badyaev 2007). This replacement is mediated by selection in the Western Bluebird for highly aggressive dispersing males at high breeding density and for less aggressive philopatric males at low breeding density, through females biasing birth order by having sons early and late in the clutch, respectively (Duckworth 2008; Duckworth et al. 2015).

The Great Grey Owl (Strix nebulosa) has a circumpolar distribution in the boreal forest of the Paleractic and Nearctic (Cramp 1985). In the western Paleartic, its range has for a long time extended through central Finland into northern Sweden (Cramp 1985). In the course of the last fifty years, however, the breeding range of the Great Grey Owl in Fennoscandia has undergone an expansion towards southwest (Stefansson 1997; Sulkava and Huhtala 1997; Valkama et al. 2011; Ottosson et al. 2012; Ławicki et al. 2013). In particular, during the last decade a remarkable colonization has occurred in an area of $\mathrm{c} 10000 \mathrm{~km}^{2}$ located in Hedmark county in south-eastern Norway on the border to Sweden (Berg 2016; Berg et al. 2019) This extends the breeding range of this species $>100 \mathrm{~km}$ towards the southwest (Fig. 1). Here, the number of recorded breeding pairs has increased from one in 2009 and three in 2010 to $>100$ in 2017 and 2018 (Fig. 2a), probably being representative of the expansion of a greater real breeding population (Berg 2016; Berg et al. 2019). In 2017 and 2018, another two nests were found even further to the south and west in two other counties (Haga and Bjerke 2017; Steen and Midtgard 2019). This expansion has been possible to follow in detail because Great Grey Owls have an iconic appearance, are large (male body mass c. $900 \mathrm{~g}$ ) and not very shy, and are often active

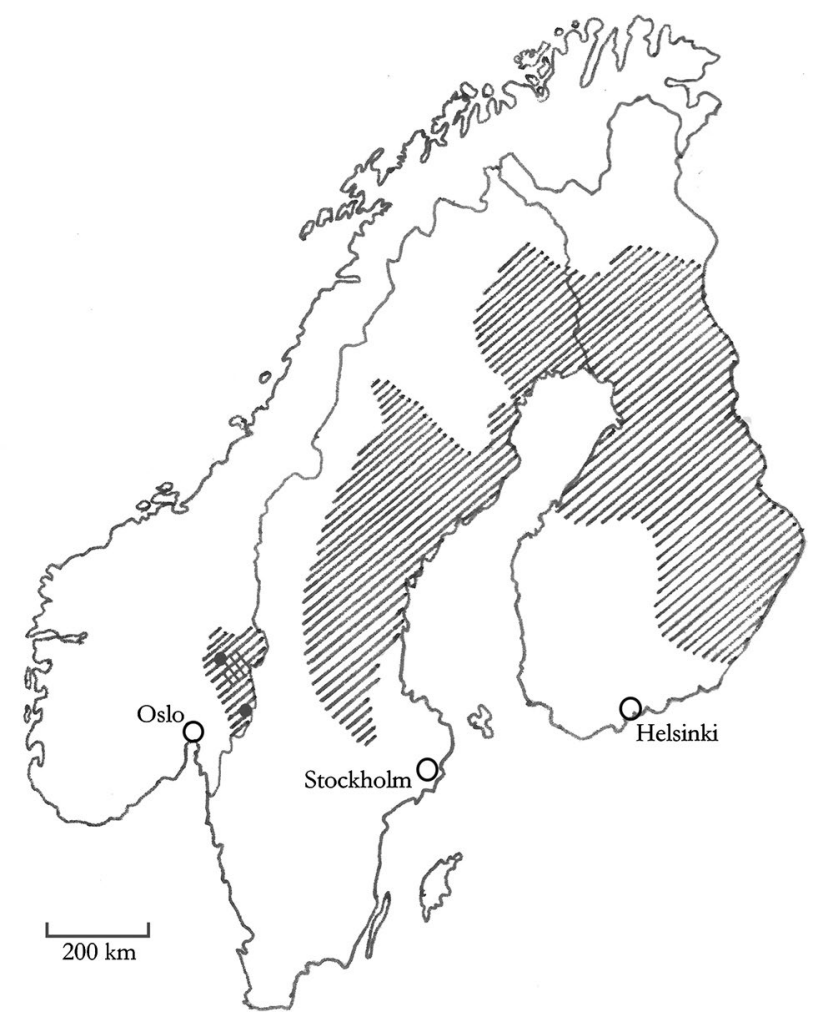

Fig. 1 The study area (hatched) and the core area (cross-hatched) in the southern part of Hedmark county, Norway, where a Great Grey Owl population was established in 2009-2011, with the pre-2009 distribution of Great Grey Owls in Sweden (Svensson et al. 1999) and Finland (Valkama et al. 2011) indicated. The two sites where data on small mammal population fluctuations were collected are marked with a dot. Data from the northern site are presented in Fig. 2a, and data from the southern site are presented in Wegge and Rolstad (2018) 
at daytime, foraging by perching in open habitats (Cramp 1985). Hence, they may quite easily be spotted by ornithologists and members of the public. In addition, the fact that Great Grey Owls nest in abandoned stick nests made by large raptors, in particular Northern Goshawk (Accipiter gentilis) and Common Buzzard (Buteo buteo), which had been monitored by local ornithologists for many years before the first Great Grey Owl was found (Berg et al. 2011), has facilitated the recording of breeding pairs. Putting up man-made nesting platforms as raptor nest surrogates (cf. Bull et al. 1987; Stefansson 1997) has added to this ability to monitor the expansion of the Great Grey Owl population. The proportion of the recorded Great Grey Owl nests in Hedmark county located at such platforms has increased from $12 \%$ in 2010-2013 to 48\% in 2016-2018 (Berg et al. 2019). Ornithologists have been eager to capture and band the breeding
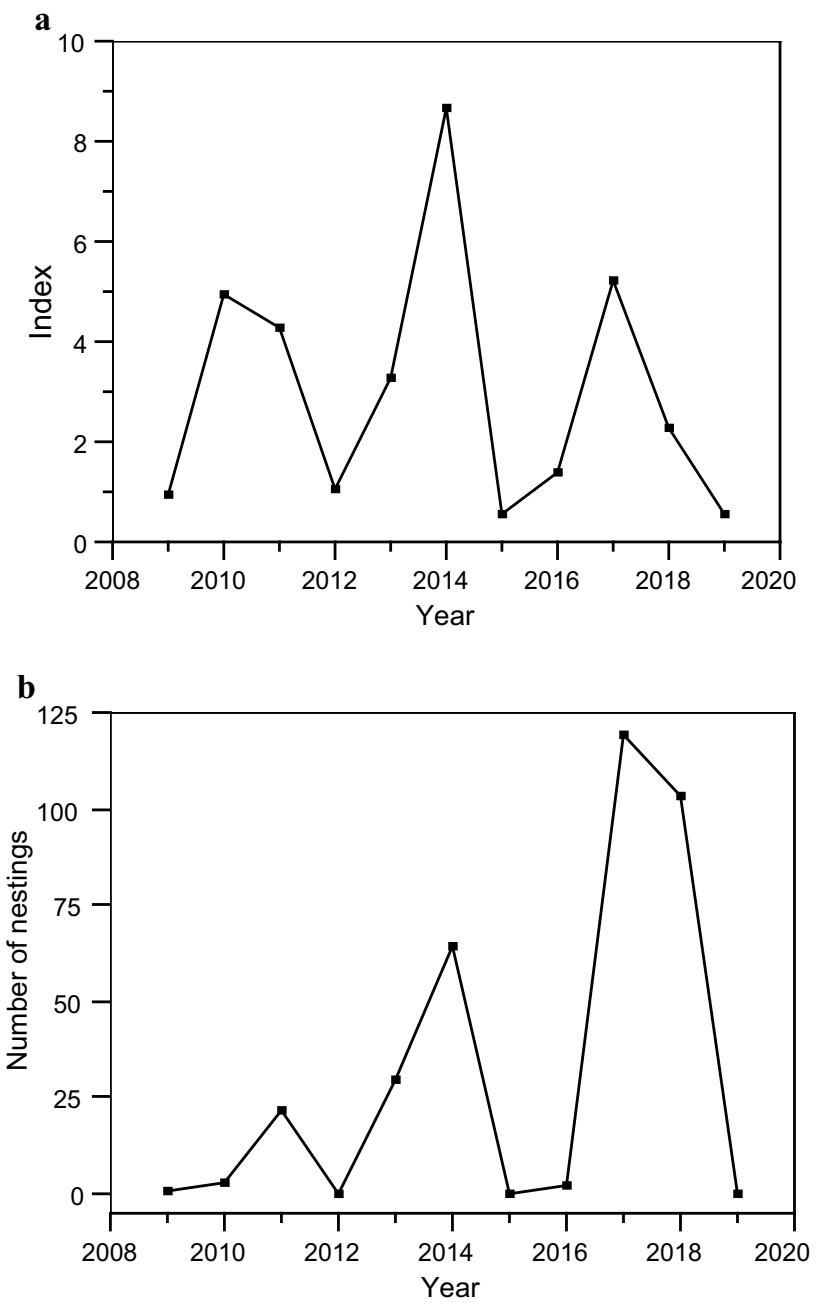

Fig. 2 Annual variation during 2009-2019 in a spring trapping index of small mammals, calculated as number of animals trapped per 100 trap nights, at the northern site in Fig. 1, and b number of Great Grey Owl nesting attempts recorded in Hedmark county, Norway owls, and to take photos of them, and this has given the opportunity to age the owls.

In long-lived owls and birds of prey most individuals do not start breeding as early as they are physiologically able to, and commonly delay breeding until they are at least $2-3$ years old. The optimal age at first breeding is affected by a complex interplay between costs and benefits of early breeding mediated by habitat heterogeneity and population density (Krüger 2005). Apart from the fact that some individuals have been recorded breeding as 1 year old (Cramp and Simmons 1980; Cramp 1985), data on age of first-time breeders are limited for most species. In the Tawny Owl (Strix aluco), 70\% started to breed as 1 year old in a population in southern Finland, with no difference between the sexes (Karell et al. 2009), while in a population in northern UK, only $27 \%$ of males and $14 \%$ of females started breeding as 1 year olds (Millon et al. 2010). In the larger Ural Owl (Strix uralensis), $16 \%$ started to breed as 1 year olds in a population in southern Finland (Brommer et al. 1998). In a population of Cooper's hawk (Accipiter cooperi) in Arizona, USA, only $14 \%$ of males and $42 \%$ of females started to breed as 1 year olds (Mannan et al. 2006), while in the larger Northern Goshawk, $42 \%$ started to breed as 1 year olds in a population in Germany (Krüger 2005).

Breeding owls have traditionally been aged based on being banded as nestlings and later recaptured as nesting adults (cf. Stefansson 1997). Molt patterns in the wings of owls can, however, be used to age the birds as long as some juvenile flight feathers are still present (e.g., Pietiäinen and Kolunen 1986; Hörnfeldt et al. 1988; Suopajärvi and Suopajärvi 1994; Solheim 2011a, b, 2012). Photos of a flying owl where the wings are fully stretched may reveal the age of the bird without having to capture it. This makes it possible to age more individuals than the ones which can be captured and examined in hand, and may even be used to recognize or separate different individuals (Solheim 2010, 2016). Being able to age an owl without having to capture it is important, because the probability of trapping an individual bird depends on its personality and sex, implying that trapping does not sample a population randomly (Garamszegi et al. 2009).

Great Grey Owls in Fennoscandia subsist almost exclusively on small mammals, i.e., shrews (Soricidae) and microtine rodents (Arvicolinae), and in particular on Microtus voles (Mikkola 1981, 1983; Cramp 1985). They show a strong numerical response to the 3-4 year small mammal population cycles, and rarely nest in years other than the two ensuing peak years (hereafter termed "peak year one" and "peak year two") of each cycle (Hipkiss et al. 2008). Therefore, we hypothesized that the proportion of 1 year olds among breeding individuals would be higher in peak year two than in peak year one of each small mammal population cycle. Further, we hypothesized that in a newly 
established and expanding population of Great Grey Owls the proportion of 1 year olds among breeding individuals would be particularly high in peak year two in the first small mammal cycle after the establishment of the Great Grey Owl population, and would decline as the population density increased. Finally, we hypothesized that there would be no difference between the sexes in the proportion of 1 year old birds breeding, and no difference in the proportion of 1 year olds between breeding birds being captured for banding and breeding non-captured birds being photographed in flight.

\section{Materials and methods}

The 344 nesting attempts of Great Grey Owls recorded in the boreal forest in Hedmark county in Norway during 2009-2019 were located in 14 municipalities in the southern half of the county (for details, see Berg 2016; Berg et al. 2019). These municipalities cover a total land area of 14 $777 \mathrm{~km}^{2}$ at c. $60^{\circ} 00^{\prime}-61^{\circ} 30^{\prime} \mathrm{N}, 10^{\circ} 30^{\prime}-12^{\circ} 30^{\prime} \mathrm{E}$ (Fig. 1), of which $9887 \mathrm{~km}^{2}$ is productive forest. The core part, consisting of five neighboring municipalities which each had $>25$ nesting attempts, in total 295 nesting attempts (see Berg 2016; Berg et al. 2019), covers $4869 \mathrm{~km}^{2}$ (Fig. 1), of which $3601 \mathrm{~km}^{2}$ is productive forest. The number of recorded nesting attempts in each municipality (1-172) was not significantly correlated with the land area of the actual municipality (Spearman's rank correlation, $r_{\mathrm{s}}=0.17, n=14, p=0.56$ ) or the area of productive forest $\left(r_{\mathrm{s}}=0.14, n=14, p=0.63\right)$. This was also the case for the core part $\left(r_{\mathrm{s}}=0.50, n=5\right.$, $p=0.39$ in both cases). In Elverum municipality, where most nesting attempts were recorded, the density in 2017 averaged 6.4 recorded nesting attempts per $100 \mathrm{~km}^{2}$ of productive forest (59 nesting attempts on $926 \mathrm{~km}^{2}$ ). A similar maximum nesting density has been recorded in Sweden and Finland (Mikkola 1981).

As many as possible of the recorded breeding owls were captured for banding or were recaptured for control of formerly banded individuals. Chicks were banded either as grown nestlings or shortly after they had left the nests, before they were able to fly properly. Adult Great Grey Owls often defend their chicks by approaching and fiercely attacking humans who come too close (Stefansson 1997). Attacking owls were captured in large scoop-nets, a dho-gaza net, or with a noose-line on a telescopic fishing rod when an owl was perching close by without attacking. A total of 165 adults ( 30 males and 135 females) and 543 chicks were banded. In addition, 48 adults were recaptured and had their leg bands read for the purpose of aging. Some of these 48 individuals were recaptured more than once, resulting in a total of 71 recaptures. Individuals that could not be captured were photographed if possible. A total of 278 nesting adult owls (64 males and 214 females) were aged, which is $40.4 \%$ of the 688 assumed possible number of individuals in the recorded 344 nesting attempts during 2009-2018 (Table 1).

The aging categories for birds proposed by Runde (1991) were used. A bird is in its first calendar year (1CY) from the time of hatching until 31 December. In the following year it is $2 \mathrm{CY}$, and so on. A bird is denoted $5 \mathrm{CY}+$ when it is in its fifth calendar year or older. The birds were aged using the molt schemes described by Suopajärvi and Suopajärvi (1994) and Solheim (2011a), supplied with later experiences with birds in age category $5 \mathrm{CY}$. For some owls photos of the bird's tail only and not the wings were obtained, so it could only be decided whether the owl had molted its juvenile retrices or not. These individuals were thus classified as either young $(2 \mathrm{CY})$ or older $(3 \mathrm{CY}+)$ adult owls.

We used one individual owl in one nesting attempt as unit in statistical tests. The 64 nesting males and 214 nesting females that we scored for age were from 217 different nests (At a few nests, the male, but not the female, was aged.). Of these 278 owls, 225 were captured for banding or were recaptured, and then aged when handled, while $53(19.1 \%)$ were photographed without being captured, and aged from the photo only (Table 1). Excluding repeated captures of the same individuals in different years to avoid pseudoreplication, we were left with 62 different males and 161 different females scored for age. Individuals being photographed, but not captured, in one year may have been captured or photographed in a later year and still recorded as different individuals.

As an index of the abundance of prey for the Great Grey Owls during the breeding season in 2009-2019 we used data collected in spring from a long-term trapping study on fluctuations of small mammal populations in

Table 1 Number of breeding Great Grey Owls aged after having been captured and banded or after being recaptured, or photographed in flight without being captured, during 2009-2019 in Hedmark county, Norway

\begin{tabular}{lrrrrr}
\hline Year & \multicolumn{2}{l}{ Number of aged individuals } & $\begin{array}{l}\text { Number } \\
\text { of nesting } \\
\text { nyttempts }\end{array}$ \\
\cline { 2 - 5 } & Banded & Recaptured & Photographed & Total & \\
\hline 2009 & 0 & 0 & 2 & 2 & 1 \\
2010 & 4 & 0 & 0 & 4 & 3 \\
2011 & 15 & 3 & 8 & 26 & 22 \\
2012 & 0 & 0 & 0 & 0 & 0 \\
2013 & 21 & 4 & 5 & 30 & 30 \\
2014 & 36 & 13 & 17 & 66 & 64 \\
2015 & 0 & 0 & 0 & 0 & 0 \\
2016 & 0 & 0 & 0 & 0 & 2 \\
2017 & 40 & 17 & 12 & 69 & 119 \\
2018 & 38 & 34 & 9 & 81 & 103 \\
2019 & 0 & 0 & 0 & 0 & 0 \\
Total & 154 & 71 & 53 & 278 & 344 \\
\hline
\end{tabular}


the northern boreal forest, conducted within our study area (Fig. 1). The distance from this site to the nearest recorded Great Grey Owl nesting attempt is c $10 \mathrm{~km}$, the distance to our core Great Grey Owl breeding area is 30-40 km, and the distance to our most distant nesting attempt is c. $130 \mathrm{~km}$. The trapping site and the trapping method are described by Sonerud $(1986,1988)$ and Selås et al. (2013). For the purpose of the present study, we use the trapping index of all small mammals species pooled, i.e., Microtus voles (Field Vole M. agrestis and Tundra Vole M. oeconomus pooled), Bank Vole (Myodes glareolus), Wood Lemming (Myopus schisticolor) and shrews [Soricidae; mostly Common Shrew (Sorex araneus)], because these are all delivered at Great Grey Owl nests (Mikkola 1981, 1983; Cramp 1985). In addition, we refer to a corresponding trapping index based on long-term data collected in fall by Wegge and Rolstad (2018) at a site in the southern part of Hedmark county, c $120 \mathrm{~km}$ south of the other trapping site (Fig. 1). All recorded Great Grey Owl nesting attempts were located $<100 \mathrm{~km}$ from one of these trapping sites, and most $<50 \mathrm{~km}$ from the northern site (Fig. 1). Together, the small mammal population fluctuations recorded at these two sites would fairly well reflect the situation in our study area, and the small mammal populations at these two sites fluctuated in close synchrony.

\section{Data analysis}

For each case of a Great Grey Owl observed nesting, we measured the following variables: (1) Age of the individual (Table 2). (2) Sex of the individual. (3) Whether the individual had been captured for banding, and its age determined when having the bird in the hand, or whether the individual had been photographed only, and its age determined later from the photo (Table 1). (4) Study year, taken as a categorical variable. (5) Type of year, i.e., whether the year was peak year one or peak year two in each small mammal population cycle. (6) Number of nesting attempts recorded the actual year, taken as a proxy for the Great Grey Owl population density.

For the statistical analysis each nesting owl was classified as either young (2 CY) or old (3 CY +), and type of year, number of nesting attempts, sex, and method of age classification, were analyzed using logistic regression in JMP ${ }^{\circledR}$ Pro version 13.0.0 (SAS 2019). Also, differences between each year in proportion of young owls were compared by contingency analysis. Because there were few observations in 2009 and 2010, these two years were pooled in the latter analysis. When these multiple tests were performed, we made sequential Bonferroni corrections (Rice 1989) because of the enhanced probability of getting $p<0.05$ by chance. However, because sequential Bonferroni corrections may be overly conservative (Moran 2003; Nakagawa 2004; Garamszegi 2006), we present the non-corrected p-values as well. Estimates are given with $\pm 1 \mathrm{SE}$.

\section{Results}

The small mammal population density in our study area during the Great Grey Owl breeding season, as measured annually in May near the core area (Fig. 1), fluctuated markedly with low levels in 2009, 2012, 2015-2016 and 2019 , with peak year one in a cycle ("increase year") in 2010, 2013 and 2017, and with peak year two in a cycle (the last year before the crash year) in 2011, 2014 and 2018 (Fig. 2a). This pattern was closely followed by the number of recorded Great Grey Owl nesting attempts (Fig. 2b; $r_{\mathrm{s}}=0.83, n=11, p=0.0017$ ).

The proportion of females among the owls observed was not significantly related to study year, neither when all observations were included $\left(\chi^{2}=8.81, \mathrm{df}=5, p=0.12\right)$, nor when only the first observation of each individual
Table 2 Number of breeding Great Grey Owls aged during 2009-2019 in Hedmark county, Norway, separated by age class (calendar year, CY), where $3 \mathrm{CY}+$ denotes individuals in their third calendar year or older, $4 \mathrm{CY}+$ denotes individuals in their fourth calendar year or older, and $5 \mathrm{CY}+$ denotes individuals in their fifth calendar year or older

\begin{tabular}{ccclclcrr}
\hline Year & 2 CY & 3 CY & 3 CY + & 4 CY & 4 CY + & 5 CY & 5 CY + & Total \\
\hline 2009 & 0 & 0 & 0 & 0 & 0 & 0 & 2 & 2 \\
2010 & 0 & 1 & 0 & 0 & 0 & 0 & 3 & 4 \\
2011 & 20 & 0 & 0 & 0 & 0 & 0 & 6 & 26 \\
2012 & 0 & 0 & 0 & 0 & 0 & 0 & 0 & 0 \\
2013 & 0 & 6 & 0 & 8 & 0 & 0 & 16 & 30 \\
2014 & 4 & 0 & 6 & 19 & 0 & 4 & 33 & 66 \\
2015 & 0 & 0 & 0 & 0 & 0 & 0 & 0 & 0 \\
2016 & 0 & 0 & 0 & 0 & 0 & 0 & 0 & 0 \\
2017 & 1 & 1 & 1 & 6 & 1 & 2 & 57 & 69 \\
2018 & 8 & 2 & 0 & 0 & 0 & 6 & 65 & 81 \\
2019 & 0 & 0 & 0 & 0 & 0 & 0 & 0 & 0 \\
Total & 33 & 10 & 7 & 33 & 1 & 12 & 182 & 278 \\
\hline
\end{tabular}




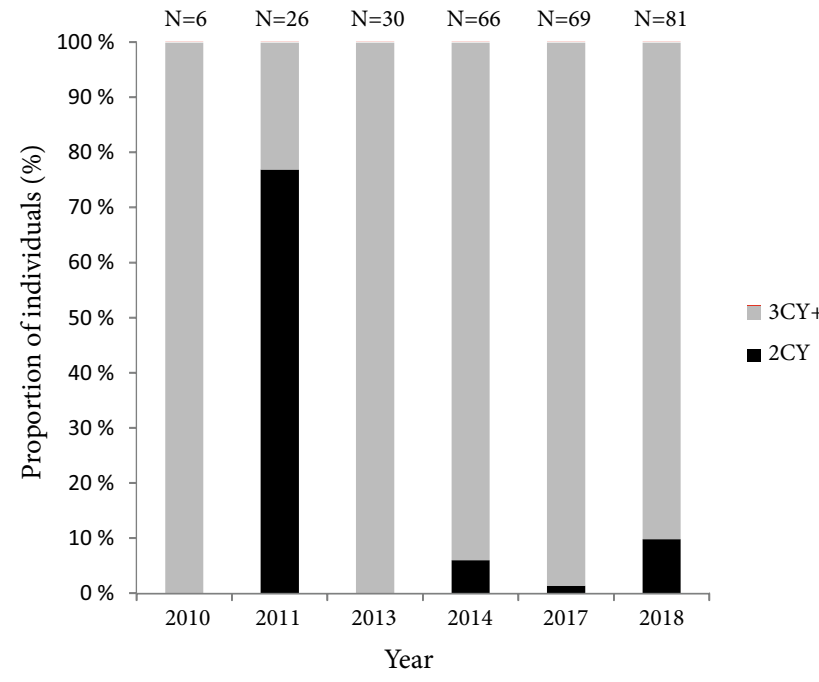

Fig. 3 Proportion of 1 year old (2 CY) individuals among breeding Great Grey Owls in Hedmark county, Norway, in peak year one $(2009 / 2010,2013,2017)$ and peak year two $(2011,2014$ and 2018) of the recurrent small mammal population cycles. Data from 2009 and 2010 are pooled and termed 2010 due to low sample size in 2009 . Sample size above the bars

observed breeding in two or more years was included $\left(\chi^{2}=6.38, \mathrm{df}=5, p=0.27\right)$. The proportion of individuals that had only been photographed was not significantly related to study year, neither when all observations were included $\left(\chi^{2}=8.57, \mathrm{df}=5, p=0.13\right)$, nor when only the first observation of each individual observed breeding in two or more years was included $\left(\chi^{2}=4.93, \mathrm{df}=5\right.$, $p=0.42$ ). The sex of an owl observed nesting was, however, highly correlated with whether the owl had been photographed only, both when all observations were included (9.8\% of females vs. $50.0 \%$ of males; $\chi^{2}=51.56, \mathrm{df}=1$, $p<0.0001)$ and when only the first observation of each individual observed breeding in two or more years was included (12.4\% of females vs. $51.6 \%$ of males; $\chi^{2}=38.45$, $\mathrm{df}=1, p<0.0001)$.

Of the nesting owls observed, $11.9 \%$ were scored as young $(2 \mathrm{CY})$ when all observations were included $(9.8 \%$ of females and $18.8 \%$ of males; $\left(\chi^{2}=3.76, \mathrm{df}=1, p=0.053\right)$, and $14.8 \%$ when only the first observation of each individual observed breeding in two or more years was included $(13.0 \%$ of females and $19.4 \%$ of males; $\chi^{2}=1.41, \mathrm{df}=1, p=0.23$ ).

The proportion of young owls was significantly higher in $2011(76.9 \%, 95 \%$ CI 60.7, 93.1) than in any other study year, both when all observations were included (Fig. 3, Table 3a), and when only the first observation of individuals observed breeding in two or more years was included (Table $3 \mathrm{~b}$ ). In addition, the proportion of young owls was significantly higher in 2018 (15.4\%) than in $2017(1.8 \%)$ and $2013(0 \%)$ when only the first observation of individuals observed breeding in two or more years was included (Table 3b), and significantly higher in 2018 (9.9\%) than in 2017 (1.5\%) when all observations were included (Table 3a). After Bonferroni correction, only the differences between 2011 and the other years were significant.

When all observations were included, the probability that a nesting Great Grey Owl was 1 year old was significantly affected by type of year and number of nesting attempts recorded (Table 4a). The probability that a nesting Great Grey Owl was 1 year old was higher in peak year two of a small mammal population cycle (18.5\%) than in peak year one $(1.0 \%)$, and declined with nesting density. There was only one 1-year old among the individuals nesting in a peak year one (in 2017). The effect of the sex of the breeding bird and the effect of method of age determination, i.e., whether the bird was captured or only photographed in flight, were not significant. The results were very similar when only the first observation of each individual recorded breeding in two or more years was included (Table $4 b$ ).

Among the 16 nestlings that were banded in the 3 known nests in 2010, no less than two were recaptured while

Table 3 Test of differences between the study years in the proportion of 1 year old individuals among breeding Great Grey Owls, when a all cases recorded are included, and $\mathbf{b}$ only one case of each individual owl recorded is included

\begin{tabular}{lccccc}
\hline Year & 2011 & 2013 & 2014 & 2017 & 2018 \\
\hline (a) & & & & & \\
2010 & $\mathbf{1 2 . 3 1}$ & 0.00 & 0.39 & 0.09 & 0.65 \\
& $\mathbf{0 . 0 0 0 5}$ & 1.00 & 0.53 & 0.77 & 0.42 \\
2011 & & $\mathbf{3 5 . 9 0}$ & $\mathbf{4 8 . 5 8}$ & $\mathbf{6 2 . 4 7}$ & $\mathbf{4 5 . 7 9}$ \\
& & $<\mathbf{0 . 0 0 0 1}$ & $<\mathbf{0 . 0 0 0 1}$ & $<\mathbf{0 . 0 0 0 1}$ & $<\mathbf{0 . 0 0 0 1}$ \\
2013 & & & 1.90 & 0.44 & 3.19 \\
& & & 0.17 & 0.51 & 0.07 \\
2014 & & & & 2.01 & 0.71 \\
& & & & 0.16 & 0.40 \\
2017 & & & & & $\mathbf{4 . 6 9}$ \\
& & & & & $\mathbf{0 . 0 3}$ \\
(b) & & & & & \\
2010 & $\mathbf{1 2 . 3 1}$ & 0.00 & 0.46 & 0.11 & 1.07 \\
& $\mathbf{0 . 0 0 0 5}$ & 1.00 & 0.50 & 0.74 & 0.30 \\
2011 & & $\mathbf{3 2 . 5 0}$ & $\mathbf{4 1 . 7 6}$ & $\mathbf{5 3 . 3 8}$ & $\mathbf{2 8 . 5 3}$ \\
& & $<\mathbf{0 . 0 0 0 1}$ & $<\mathbf{0 . 0 0 0 1}$ & $<\mathbf{0 . 0 0 0 1}$ & $<\mathbf{0 . 0 0 0 1}$ \\
2013 & & & 1.95 & 0.46 & $\mathbf{4 . 4 6}$ \\
& & & 0.16 & 0.50 & $\mathbf{0 . 0 3}$ \\
2014 & & & & 1.94 & 1.85 \\
& & & & 0.16 & 0.17 \\
2017 & & & & & $\mathbf{6 . 6 7}$ \\
& & & & & \\
\hline
\end{tabular}

For each combination of two years, the upper value is Pearson chisquare, and the lower value is $p$. Significant values are in bold, and marginally non-significant values are in italic 
Table 4 Effects of type of year, nesting density, sex, and method of age determination on the probability that a breeding Great Grey Owl was 1 year old rather than at least 2 years old, with parameter estimates from Wald test, when a all cases recorded are included $(n=278)$, and b only one case of each individual owl recorded is included $(n=223)$

\begin{tabular}{lrrrl}
\hline Estimate \pm SE & \multicolumn{1}{c}{$\chi^{2}$} & \multicolumn{2}{c}{$\mathrm{df}$} & $p$ \\
\hline (a) & & & & \\
Intercept & $-4.99 \pm 0.91$ & 30.14 & & $<0.0001$ \\
Type of year & $-3.26 \pm 0.83$ & 15.53 & 1 & $<0.0001$ \\
Nesting density & $-1.41 \pm 0.27$ & 26.39 & 1 & $<0.0001$ \\
Sex & $-0.21 \pm 0.26$ & 0.63 & 1 & 0.43 \\
Method & $0.21 \pm 0.29$ & 0.50 & 1 & 0.48 \\
(b) & & & & \\
Intercept & $-4.38 \pm 0.86$ & 26.21 & & $<0.0001$ \\
Type of year & $-2.97 \pm 0.79$ & 14.13 & 1 & $<0.0001$ \\
Nesting density & $-1.32 \pm 0.29$ & 20.67 & 1 & $<0.0001$ \\
Sex & $-0.09 \pm 0.25$ & 0.12 & 1 & 0.73 \\
Method & $0.24 \pm 0.28$ & 0.71 & 1 & 0.40 \\
\hline
\end{tabular}

Nesting density denotes the annual recorded number of recorded nesting attempts (1-119, $\log _{10}$-transformed and standardized), type of year denotes whether the year was peak year one $(2010,2013,2017)$ or peak year two $(2011,2014,2018)$ in the recurrent $3-4$ years small mammal population cycles (2009 was scored as peak year one), and method denotes whether age was determined after the owl had been captured or after when it had been photographed in flight only. a Whole model: $\chi^{2}=60.65, \mathrm{df}=4, p<0.0001, R^{2}=0.30$, model fit $\chi^{2}$ / $\mathrm{df}=1.55$. b Whole model: $\chi^{2}=54.48, \mathrm{df}=4, p<0.0001, R^{2}=0.29$, model fit $\chi^{2} / \mathrm{df}=1.58$

breeding in the study area in 2011 . In contrast, only three of the 203 nestlings banded in 2013 and 2017 were recaptured while breeding in the study area in 2014 or 2018. This difference is significant $\left(12.5 \%\right.$ vs. $1.5 \% ; \chi^{2}=8.08, \mathrm{df}=1$, $p=0.0045$ ). Thus, a higher proportion of the young produced in peak year one was recruited to the local population in peak year two during the first small mammal cycle after the establishment of the great Grey Owl population than during the next two cycles.

To sum up, during our study the proportion of 1 year old individuals among the breeding Great Grey Owls was higher in peak year two in each of the three small mammal population cycles $(2011,2014$ and 2018) than in peak year one in each of the three small mammal population cycles (2010, 2013 and 2017). It was also higher in peak year two in the first of the three cycles when the Great Grey Owl population density was low than in peak year two in the two later cycles when the Great Grey population density was higher.

\section{Discussion}

Among the breeding Great Grey Owls in our study, $12 \%$ were 1 year old, and $16 \%$ were 1 or 2 years old. In 2011 , $77 \%$ were scored as 1 year old, compared to $5 \%$ in the later years. Including the 2 years old owls, the corresponding figures were $77 \%$ and $10 \%$, respectively, so in the years other than 2011, 90\% of the breeding owls were at least 3 years old. In an established population of the Great Grey Owl in northern Sweden, only $4 \%$ of the nesting individuals were scored as 1 year old, and another 5\% as 2 years old, so $91 \%$ of the individuals were scored as 3 years or older (Solheim and Stefansson 2016). Thus, the age distribution of our study population from 2013 onwards was remarkably similar to that in the established population in northern Sweden. The aging of nesting owls in the Swedish population was, however, based on recaptures of birds banded as chicks only, and not on wing feather characteristics (cf. Solheim 2011a).

The year with the exceptionally high proportion of 1 year old individuals among the breeding Great Grey Owls in our study (2011) was preceded by a small mammal peak year one (2010) and followed by the low year 2012 (cf. Wegge and Rolstad 2016). Thus, the 1 year old owls were hatched in the first of the two sequential peak years of a small mammal population cycle (2010). The proportion of 1 year olds among the nesting Great Grey Owls was relatively high in 2014 (7\%) and 2018 (13\%), which both were the second peak year in a small mammal population cycle and followed by a low year (2015 and 2019, respectively; cf. Wegge and Rolstad 2016). In a population of Ural Owls in Finland, 16\% of the nesting individuals were 1 year old (Brommer et al. 1998). Here, nesting at one year of age was conditional on being hatched in peak year one of a vole population cycle; $42 \%$ of the breeding Ural Owls were 1 year old in peak year two in the vole population cycle, compared to only $3 \%$ in peak year one and 0\% in the low year (Brommer et al. 1998). In a population of Tawny Owls in northern England, where the population density of its main prey species, the Field Vole, fluctuated with a 3 year cycle, owls of both sexes that started to breed at an age of 1 year did so almost exclusively in the years with peak vole density in spring, whereas those that were 2 years or older when breeding for the first time did so in low or increase vole years (Millon et al. 2010). Similarly, in a population of Tawny Owls in southern Finland where voles also exhibited a 3 year density cycle, age at first breeding was lowest for owls starting to breed in the year with peak vole density in spring, and higher for those starting to breed in the low or the increase year of the vole cycle (Karell et al. 2009).

The proportion of 1 year old Great Grey Owls in our study was much higher in 2011 than in the corresponding phase of the next two small mammal population cycles 
(2014-2018). The population density of Great Grey Owls in our study area was far lower in 2011 (22 nesting attempts recorded) than in 2014 (64 nesting attempts recorded) and in 2018 (103 nesting attempts recorded). Thus, the probability of a 1 year old Great Grey Owl nesting declined as the population density increased. Similarly, in a newly established population of the Northern Goshawk in Hamburg, Germany, a large proportion of breeding recruits were 1-2 years old (Rutz 2008). This is characteristic of young or expanding Northern Goshawk populations, while in undisturbed, established populations, first-time breeders are usually at least 3 years old (Rutz et al. 2006). In both sexes of the Eurasian Sparrowhawk (Accipiter nisus) in the UK the proportion of 1 year old breeders was higher in a newly established and expanding population than in either an established and stable population or in a declining population (Wyllie and Newton 1991)

In 2014, four of the 66 aged breeding owls were 4 years old $(5 \mathrm{CY})$, and 33 were at least four years old. Thus, a relatively high proportion of the owls breeding this year had hatched in 2010 or earlier. Some of these birds would therefore have been from the same cohort as the birds we found nesting at an age of 1 year in 2011. Therefore, an alternative, or additional, explanation for the declining probability of finding a 1 year old Great Grey Owl nesting as the population density increased would simply be a larger proportion of individuals from the 2010-cohort in the breeding population as the years passed.

At least $61 \%$ of the Great Grey Owls breeding in our study area in 2011 were 1 year old. If these birds were locally recruited, each pair breeding in 2010 must have produced at least 3 recruits, i.e., 3 fledglings if there was no mortality from time of fledging until breeding next year, or 6 fledglings if there was 50\% mortality the first year. Brood size at fledging, taken as the average number of young banded per brood, was 5.3 in 2010, the highest recorded during the study, although based on a low sample size (Berg 2016). Given that the real proportion of 1 year old individuals among the Great Grey Owls breeding in our study area in 2011 may have been as high as $93 \%$, it can hardly be explained from the local production alone. Most likely there was an influx of juvenile birds to our study area from areas further east in Sweden, adding to the local population of juvenile birds. This is supported by the fact that two of the 1 year old Great Grey Owl males that were found breeding in 2011 had been banded as nestlings in our study area in 2010, $6 \mathrm{~km}$ and $50 \mathrm{~km}$ away, respectively, and one of the 1 year old females had been banded as nestlings in 2010 in Dalarna county in Sweden, $126 \mathrm{~km}$ to the east. Also, a female recaptured while breeding in our study area in 2017 had been banded as a nestling in Sweden in 2010, $325 \mathrm{~km}$ towards northeast, supporting our view of 2010 as a year of good reproduction for Great Grey Owls in central Sweden.
A third Swedish-banded female was recaptured breeding in our study area in 2010, $159 \mathrm{~km}$ west of where she had been banded as a nestling in 1999. As a curiosity, she had hatched in a nest only $440 \mathrm{~m}$ from the nest where the female recaptured in 2011 had hatched, although 11 years earlier. In an established population of the Great Grey Owl in northern Sweden, mean natal dispersal distance was $40 \mathrm{~km}$ for females breeding as 1 year olds and $76 \mathrm{~km}$ for all females (Solheim and Stefansson 2016).

We do not know much of what the Great Grey Owls hatched in our study area in peak year one of the small mammal population cycles 2013-2014 and 2017-2018 were doing in peak year two, apart from the fact that two females banded as nestlings in 2013 were recaptured while nesting $2 \mathrm{~km}$ and $25 \mathrm{~km}$ away, respectively, in 2014, and that a third female banded as nestling in 2017 was recaptured while nesting $15 \mathrm{~km}$ away in 2018. Most of the owls hatched in our study area in 2013-2017 were certainly not among the nesters recorded and aged here in 2014-2018, respectively. These 1 year old birds may therefore either have postponed nesting, or dispersed into other parts of south-eastern Norway in a still expanding population, or into the established breeding range towards east and northeast in Sweden. Of the 66 aged breeders in 2014 no less than 23 (35\%) were 3 years old birds and 4 years old birds, which further supports our interpretation that 2010-2011 were years with a high reproduction in Great Grey Owls in central Sweden and bordering areas in Norway. This was also reflected in the age distribution of the non-breeding Great Grey Owls observed in Norway and Sweden in 2012, with a high proportion of 2CY birds (Solheim 2014).

The proportion of 1 year old Great Grey Owls in our study tended to be higher among nesting males than among nesting females. Similarly, age at first breeding was lower among males (median 2 years) than among females (median 3 years) in a population of Tawny Owls in northern England (Millon et al. 2010). However, this was not the case in a population of Tawny Owls in southern Finland (Karell et al. 2009).

The proportion of the breeding owls that were aged based on photos only was higher for males than for females. This is because males were far more difficult to capture than were females, because they showed less aggression towards intruders at the nest and were thus less likely to attack or approach close enough to allow a capture attempt.

In conclusion, the Great Grey Owl population of $>100$ recorded nesting pairs in Hedmark county in south-eastern Norway in 2017-2018 seems to have been founded to a large extent by birds nesting as 1 year olds in 2011, of which most had likely dispersed towards southwest and west from Sweden. Our data set on the age of the nesting owls was extended due to the possibility to determine the age of the birds from photos without having to capture them. Being able to age 
an owl without having to capture it is important, because trapping does not sample a bird population randomly (Garamszegi et al. 2009). Future studies on age structure in owl populations should sample data by taking pictures of the owls in flight in addition to, or instead of, capturing them.

Acknowledgements Open Access funding provided by Norwegian University of Life Sciences. We thank all the local ornithologists and bird banders who have helped us with field work and reports of nesting Great Grey Owls, in particular E. Østby, R. Huldt, R. Svenkerud, G. C. Nyhus, H. Likvern, A. Mæhlen, C. S. Torjussen, M. Holmsand, C. Steel, M. Erichsen and T. Wernberg. We also thank R. Burner, S. Dale, V. Selås, C. S. Torjussen and two anonymous reviewers for constructive comments on drafts of the manuscript. The Norwegian Environment Agency granted permissions to capture and band the Great Grey Owls and to trap small mammals.

Author contributions RS originally formulated the idea, RS and TB developed the methodology and collected the data on the owls, GAS collected the data on the small mammals, RS, TB and GAS organized the data, GAS did the statistical analysis, GAS and RS wrote the paper, and TB made editorial contribution.

\section{Compliance with ethical standards}

Conflicts of interests The authors declare that they have no conflict of interest in the authorship of this article. Use of product or corporation names is for descriptive purposes only and implies no endorsement by any author or affiliation.

Ethical approval All applicable institutional and/or national guidelines for the care and use of animals were followed.

Open Access This article is licensed under a Creative Commons Attribution 4.0 International License, which permits use, sharing, adaptation, distribution and reproduction in any medium or format, as long as you give appropriate credit to the original author(s) and the source, provide a link to the Creative Commons licence, and indicate if changes were made. The images or other third party material in this article are included in the article's Creative Commons licence, unless indicated otherwise in a credit line to the material. If material is not included in the article's Creative Commons licence and your intended use is not permitted by statutory regulation or exceeds the permitted use, you will need to obtain permission directly from the copyright holder. To view a copy of this licence, visit http://creativecommons.org/licenses/by/4.0/.

\section{References}

Berg T (2016) Lappuglehekkinger i Hedmark 1989-2016. Rapport, Fylkesmannen i Hedmark (In Norwegian)

Berg T, Solheim R, Wernberg T, Østby E (2011) Lappuglene kom! Vår Fuglefauna 34:108-115 (In Norwegian)

Berg T, Østby E, Huldt R, Svenkerud R, Solheim R (2019) Lappuglehekking i Hedmark 2016-2018. Vår Fuglefauna 42:78-83 (In Norwegian.)

Brommer JE, Pietiäinen H, Kolunen H (1998) The effect of age at first breeding on Ural owl life time reproductive success and fitness under cyclic food conditions. J Anim Ecol 67:359-369
Bull EL, Henjum MG, Anderson RG (1987) Nest platforms for great gray owls. In: Nero RW, Clark RJ, Knapton RJ, Hamre RH (eds) Biology and conservation of the northern forest owls: symposium proceedings. US Department of Agriculture, Forest Service, General Technical Report RM-142, Fort Collins, Colorado, pp 87-90

Cramp S, Simmons KEL (eds) (1980) The birds of the Western Palearctic, vol II. Oxford University Press, Oxford

Cramp S (ed) (1985) The birds of the Western Palearctic, vol IV. Oxford University Press, Oxford

Duckworth RA (2008) Adaptive dispersal strategies and the dynamics of a range expansion. Am Nat 172:S4-S17. https://doi. org/10.1086/588289

Duckworth RA, Badyaev AV (2007) Coupling of dispersal and aggression facilitates the rapid range expansion of a passerine bird. Proc Natl Acad Sci USA 104:15017-15022 (10.1073_pnas.0706174104)

Duckworth RA, Belloni V, Anderson SR (2015) Cycles of species replacement emerge from locally induced maternal effects of offspring behavior in a passerine bird. Science 347:875-877. https://doi.org/10.1126/science. 1260154

Garamszegi LZ (2006) Comparing effect sizes across variables: generalization without the need for Bonferroni correction. Behav Ecol 17:682-687. https://doi.org/10.1093/beheco/ark005

Garamszegi LZ, Eens M, Török J (2009) Behavioural syndromes and trappability in free-living collared flycatchers, Ficedula albicollis. Anim Behav 77:803-812. https://doi.org/10.1016/j. anbehav.2008.12.012

Haga A, Bjerke BA (2017) Lappuglene kommer til Østfold. Vår Fuglefauna 40:132-135 (In Norwegian)

Hipkiss T, Stefansson O, Hörnfeldt B (2008) Effect of cyclic and declining food supply on great grey owls in boreal Sweden. Can J Zool 86:1426-1431. https://doi.org/10.1139/Z08-131

Hörnfeldt B, Carlsson B-G, Nordström A (1988) Molt of primaries and age determination in Tengmalm's owl (Aegolius funereus). Auk 105:783-789

Karell P, Ahola K, Karstinen T, Zolei A, Brommer JE (2009) Population dynamics in a cyclic environment: consequences of cyclic food abundance on tawny owl reproduction and survival. J Anim Ecol 78:1050-1062. https://doi.org/10.111 1/j.1365-2656.2009.01563.x

Karvonen J, Orell M, Rytkönen S, Broggi J, Belda E (2012) Population dynamics of an expanding passerine at the distribution margin. J Avian Biol 43:102-108. https://doi.org/10.1111/j.1600048X.2011.05376.X

Krüger O (2005) Age at first breeding and fitness in goshawk Accipiter gentilis. J Anim Ecol 74:266-273. https://doi.org/10.111 1/j.1365-2656.2004.00920.x

Ławicki Ł, Abramčuk AV, Domashevsky SV, Paal U, Solheim R, Chodkiewicz T, Woźniak (2013) Range extension of great grey owl in Europe. Dutch Birding 35:145-154

Mannan RW, Mannan RN, Schmidt CA, Estes-Zumpf WA, Boal CW (2006) Influence of natal experience on nest-site selection by urban-nesting Cooper's hawk. J Wildl Manage 71:64-68 (10.2193.2005-654)

Mikkola H (1981) Der Bartkauz. Ziemzen, Wittenberg Lutherstadt (In German)

Mikkola H (1983) Owls of Europe. Poyser, Calton

Millon A, Petty SJ, Lambin X (2010) Pulsed resources affect the timing of first breeding and lifetime reproductive success of tawny owls. J Anim Ecol 79:426-435. https://doi.org/10.111 1/j.1365-2656.2009.01637.x

Moran MD (2003) Arguments for rejecting the sequential Bonferroni in ecological studies. Oikos 100:403-405

Nakagawa S (2004) A farewell to Bonferroni: the problems of low statistical power and publication bias. Behav Ecol 15:1044-1045. https://doi.org/10.1093/beheco/arh107 
Newton I (2003) The speciation and biogeography of birds. Academic Press, London

Ottosson U, Ottvall R, Elmberg J, Green M, Gustafsson R, Haas F, Holmqvist N, Lindstrøm A, Nilsson L, Svensson M, Svensson S, Tjernberg M (2012) Fåglarna i Sverige: antal och förekomst. Halmstad. (In Swedish)

Pietiäinen H, Kolunen H (1986) Age determination of breeding Ural owls. Ornis Fennica 63:26-27

Rice WR (1989) Analyzing tables of statistical tests. Evolution 43:223-225

Runde O (1991) Ringmerkerens håndbok. Stavanger Museum, Stavanger (In Norwegian)

Rutz C (2008) The establishment of an urban bird population. J Anim Ecol 77:1008-1019. https://doi.org/10.111 1/j.1365-2656.2008.01420.x

Rutz C, Bijlsma RG, Marquiss M, Kenward RE (2006) Population limitation in the northern goshawk in Europe: a review with case studies. Stud Avian Biol 31:158-197

SAS (2019) JMP ${ }^{\circledR}$ Pro version 13.0. SAS Institute, Cary

Selås V, Kobro S, Sonerud GA (2013) Population fluctuations of moths and small rodents in relation to plant production indices in southern Norway. Ecosphere 4(19):123. https://doi.org/10.1890/ ES13-00228.1

Solheim R (2010) Kan lappugglor individbestämmas utan infångande och märkning? Vår Fågelvärld 69(2):8-12 (In Swedish)

Solheim R (2011a) Molt pattern of primaries and secondaries during first and second flight feather molt in Great Grey Owls Strix nebulosa. Ornis Svecica 21:11-19

Solheim R (2011b) Moult pattern of primaries and secondaries in Eagle Owl Bubo bubo. Ornis Norvegica 34:1-9

Solheim R (2012) Wing feather moult and age determination of Snowy Owls Bubo scandiacus. Ornis Norvegica 35:48-67

Solheim R (2014) Age of Great Grey Owls Strix nebulosa observed in Scandinavia in 2012 as revealed by digital photos in the national species report archives. Ornis Svecica 24:3-11

Solheim R (2016) Individual identification of Snowy Owls (Bubo scandiacus) and Great Grey Owls (Strix nebulosa) based on wing bar patterns. J Raptor Res 50:370-378
Solheim R, Stefansson O (2016) Life span, dispersal and age of nesting Great Grey Owls (Strix nebulosa lapponica) in Sweden. Ornis Svecica 26:125-134

Sonerud GA (1986) Effect of snow cover on seasonal changes in diet, habitat and regional distribution of raptors that prey on small mammals in boreal zones of Fennoscandia. Holarct Ecol 9:33-47

Sonerud GA (1988) What causes extended lows in microtine cycles? Analysis of fluctuations in sympatric shrew and microtine populations in Fennoscandia. Oecologia 76:37-42

Steen OF, Midtgard H (2019) Hekking av lappugle dokumentert i Buskerud i 2018. Vår Fuglefauna 42:30-31 (In Norwegian)

Stefansson O (1997) Nordanskogens vagabond. Ord and Visor, Skellefteå, Lappugglan (Strix nebulosa lapponica), Boden (In Swedish with English summaries)

Sulkava S, Huhtala K (1997) The Great Grey Owl (Strix nebulosa) in the changing forest environment of northern Europe. J Raptor Res 31:151-159

Suopajärvi P, Suopajärvi M (1994) Lapinpöllön iän määrittäminen. Linnut 29(2):27-30 (In Finnish with English summary)

Svensson S, Svensson M, Tjernberg M (1999) Svensk fågelatlas. Vår Fågelvärld Supplement 31, Stockholm. (In Swedish)

Valkama J, Vepsäläinen V, Lehikoinen A (2011) The third Finnish breeding bird atlas. Finnish museum of natural history and ministry of environment. ISBN 978-952-10-7145-4. http://atlas3.lintu atlas.fi/english. Accessed 11 Sept 2019

Wegge P, Rolstad J (2018) Cyclic small rodents in boreal forests and the effects of even-aged forest management: patterns and predictions from a long-term study in southeastern Norway. Forest Ecol Manage 422:79-86. https://doi.org/10.1016/j.foreco.2018.04.011

Wyllie I, Newton I (1991) Demography of an increasing population of sparrowhawks. J Anim Ecol 60:749-766

Publisher's Note Springer Nature remains neutral with regard to jurisdictional claims in published maps and institutional affiliations. 